\title{
Altered Baseline and Nicotine-Mediated Behavioral and Cholinergic Profiles in ChAT-Cre Mouse Lines
}

\author{
-Edison Chen, ${ }^{\star}$ Valeria Lallai, ${ }^{\star}$ Yasmine Sherafat, Nickolas P. Grimes, Anna N. Pushkin, JP Fowler, \\ and $\mathbb{C}^{\text {Christie D. Fowler }}$ \\ Department of Neurobiology and Behavior, University of California Irvine, Irvine, California 92697
}

The recent development of transgenic rodent lines expressing cre recombinase in a cell-specific manner, along with advances in engineered viral vectors, has permitted in-depth investigations into circuit function. However, emerging evidence has begun to suggest that genetic modifications may introduce unexpected caveats. In the current studies, we sought to extensively characterize male and female mice from both the $\left.\mathrm{ChAT}_{(\mathrm{BAC})}\right)^{-}$Cre mouse line, created with the bacterial artificial chromosome $(\mathrm{BAC})$ method, and $\mathrm{ChAT}_{(\mathrm{IRES})}{ }^{-} \mathrm{Cre} \mathrm{mouse}$ line, generated with the internal ribosome entry site (IRES) method. $\mathrm{ChAT}_{(\mathrm{BAC})}$-Cre transgenic and wild-type mice did not differ in general locomotor behavior, anxiety measures, drug-induced cataplexy, nicotine-mediated hypolocomotion, or operant food training. However, $\mathrm{ChAT}_{(\mathrm{BAC})}-$ Cre transgenic mice did exhibit significant deficits in intravenous nicotine self-administration, which paralleled an increase in vesicular acetylcholine transporter and choline acetyltransferase (ChAT) hippocampal expression. For the $\mathrm{ChAT}_{\text {(IRES) }}-\mathrm{Cre}$ line, transgenic mice exhibited deficits in baseline locomotor, nicotine-mediated hypolocomotion, and operant food training compared with wild-type and hemizygous littermates. No differences among $\mathrm{ChAT}_{(\mathrm{IRES})}$-Cre wild-type, hemizygous, and transgenic littermates were found in anxiety measures, drug-induced cataplexy, and nicotine self-administration. Given that increased cre expression was present in the $\mathrm{ChAT}_{(\mathrm{IRES})}-$ Cre transgenic mice, as well as a decrease in ChAT expression in the hippocampus, altered neuronal function may underlie behavioral phenotypes. In contrast, $\mathrm{ChAT}_{(\mathrm{IRES})}$-Cre hemizygous mice were more similar to wild-type mice in both protein expression and the majority of behavioral assessments. As such, interpretation of data derived from ChAT-Cre rodents must consider potential limitations dependent on the line and/or genotype used in research investigations.

Key words: acetylcholine; choline acetyltransferase; cre recombinase; intravenous nicotine self-administration; mice; transgenic

\section{Significance Statement}

Altered baseline and/or nicotine-mediated behavioral profiles were discovered in transgenic mice from the $\mathrm{ChAT}_{(\mathrm{BAC})}{ }^{-\mathrm{Cre}}$ and $\mathrm{ChAT}_{\text {(IRES) }}$-Cre lines. Given that these cre-expressing mice have become increasingly used by the scientific community, either independently with chemicogenetic and optogenetic viral vectors or crossed with other transgenic lines, the current studies highlight important considerations for the interpretation of data from previous and future experimental investigations. Moreover, the current findings detail the behavioral effects of either increased or decreased baseline cholinergic signaling mechanisms on locomotor, anxiety, learning/memory, and intravenous nicotine self-administration behaviors.

\section{Introduction}

The generation of transgenic, knock-in, and knock-out rodent lines has led to significant advances in our understanding of the

\footnotetext{
Received May 25, 2017; revised Jan. 11, 2018; accepted Jan. 12, 2018

Author contributions: E.C., V.L., N.P.G., and C.D.F. wrote the first draft of the paper; E.C., V.L., Y.S., N.P.G., A.N.P., J.F., and C.D.F. edited the paper; E.C., V.L., J.F., and C.D.F. designed research; E.C., V.L., Y.S., N.P.G., A.N.P., J.F., and C.D.F. performed research; C.D.F. contributed unpublished reagents/analytic tools; E.C., V.L., N.P.G., and C.D.F. analyzed data; E.C., V.L., and C.D.F. wrote the paper.

This work was supported by Grants from the National Institute on Drug Abuse (DA032543 and DA039658 to C.D.F.). We thank the following individuals for technical assistance in aspects of the project: Annalee Loeffler, Fatemeh Nosrati, Catherine Chiou, Lyan Hoang, and Amina Ahmed.

The authors declare no competing financial interests.

*E.C. and V.L. contributed equally to this work.

Correspondence should be addressed to Dr. Christie Fowler, Department of Neurobiology and Behavior, University of California, Irvine, 1232 McGaugh Hall, Irvine, CA 92697. E-mail: cdfowler@uci.edu.
}

mechanisms mediating normal and disease-relevant physiological function. Indeed, given the recent development of transgenic rodent lines expressing cre recombinase in a cell-specific manner, a vast number of strains with varying gene promoters have become a desirable resource for investigations into circuit function (Fowler and Kenny, 2012; Nair et al., 2013). In the GENSAT database alone, expression profiles can be found for 238 of 289 developed cre lines (GENSAT, 2017). Recent studies into circuit function have integrated these cre driver lines with optogenetic or chemicogenetic methods across fields to study learning, memory, sleep, circadian cycle, olfactory signaling, emotional states, and 
motivated behaviors (Yasuda and Mayford, 2006; Liu et al., 2015; Smith et al., 2015; Van Dort et al., 2015; Xu et al., 2015; Caggiano et al., 2016; Roseberry et al., 2016; Zant et al., 2016).

However, emerging evidence has begun to suggest that the method of development may introduce unexpected phenotypic variation into some mouse lines. For instance, the channelrhodopsin-expressing ChATChR2-EYFP transgenic line has been shown to exhibit attentional deficits, altered learning and memory processing, and enhanced motor endurance, all of which were attributed to overexpression of functional vesicular acetylcholine transporter (VAChT), leading to increased baseline cholinergic tone (Kolisnyk et al., 2013). Subsequent studies with these mice have demonstrated increased amphetamineinduced stereotypy, age-related motor effects, and neuromuscular junction structural deficits (Crittenden et al., 2014; Sugita et al., 2016). Thus, data derived from studies examining neural function with this line may be confounded due to the abnormal physiological state.

Although transgenic rodent models have opened up investigations into systems that were previously inaccessible due to methodological limitations, such as with genetic manipulations resulting in early lethality or gross phenotypic effects (Gong et al., 2007; Fowler and Kenny, 2012), extensive characterization of each rodent line within a novel system must be undertaken to ensure that valid conclusions can be drawn from experimental findings. In the current investigations, we sought to characterize the widely used ChAT-Cre mouse lines: $\mathrm{ChAT}_{(\mathrm{BAC})}-\mathrm{Cre}$ and $\mathrm{ChAT}_{(\mathrm{IRES})}{ }^{-\mathrm{Cre}}$. In generating the $\mathrm{ChAT}_{(\mathrm{BAC})}$-Cre mice, a large construct with fragments of genomic DNA were used to target cre expression GENSAT, 2017 (Ting and Feng, 2014). The clones were then engineered in bacterial host cells for subsequent integration into the genome via random integration. Although the DNA insert has been considered to be advantageous with respect to limiting transgene silencing or mosaic expression (Bian and Belmont, 2010), other aspects of this method may introduce experimental limitations, such as variable expression patterns across generations or overexpression of alternate genes found within the bacterial artificial chromosome (BAC) vector. The choline acetyltransferase (ChAT) BAC clone currently available, which was used to generate the $\mathrm{ChAT}_{(\mathrm{BAC})}$-Cre GM60 mouse line in the current study, contains several other genes in the vector, including the VAChT gene Slc18a3, and this same BAC ID (RP23-246B12) was used to generate the $\mathrm{ChAT}_{(\mathrm{BAC})}$-Cre mouse lines GM24 and GM53 and the recombinase driver ChAT-Cre rat line (Gong et al., 2007; Witten et al., 2011; Ting and Feng, 2014). Moreover, the EGFP reporter and channelrhodopsin ChAT lines similarly contain Slc18a3, although a different BAC clone was used (Gong et al., 2003; Tallini et al., 2006; Zhao et al., 2011; Ting and Feng, 2014). Given the limitations of the BAC method, novel approaches have been introduced to more specifically target cre expression. In the internal ribosome entry site (IRES) method, the IRES-Cre sequence has been inserted downstream of the ChAT gene promotor to generate ChAT (IRES) -Cre mice (Rossi et al., 2011). This vector contains the IRES-linked cre gene and frt-flanked neomycin resistance cassette, but not any other genes, and thus should theoretically result in unaltered ChAT expression. In the current studies, we provide evidence that transgenic mice from both the $\mathrm{ChAT}_{(\mathrm{BAC})}$-Cre and $\mathrm{ChAT}_{(\mathrm{IRES})}$-Cre mouse lines have significant differences in baseline and/or nicotine-mediated behaviors, which may be attributed to altered cholinergic and/or cre-mediated effects.

\section{Materials and Methods}

Animals

Male and female mice were derived from breeders in our laboratory animal facilities. $\mathrm{ChAT}_{(\mathrm{BAC})}$-Cre mice were originally obtained from the MMRRC (Strain B6.FVB(Cg)-Tg(Chat-cre)GM60Gsat/Mmucd; https://www.mmrrc. org/catalog/sds.php?mmrrc_id=30869; RRID:MMRRC_030869-UCD) and bred as transgenic $\times$ wild-type mating pairs. $\mathrm{ChAT}_{(\mathrm{IRES})}$-Cre mice were ob-

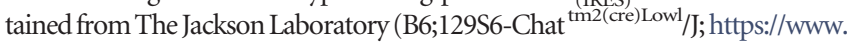
jax.org/strain/006410; RRID:IMSR_JAX:006410) and bred as hemizygous $\times$ hemizygous mating pairs. For these studies, both lines had been backcrossed onto the C57BL/6 background for at least 10 generations. Experimental subjects in all studies consisted of littermates (e.g., wild-type or transgenic littermates of the $\mathrm{ChAT}_{(\mathrm{BAC})}$-Cre line, and wild-type, hemizygous or transgenic littermates of the $\mathrm{ChAT}_{(\mathrm{IRES})}$-Cre line). To further examine the profile of cre expression, both lines were crossed to the ROSA ${ }^{26 S o r}$-tdTomato reporter line from The Jackson Laboratory (Strain B6.Cg-Gt(ROSA)26Sortm14(CAG-tdTomato) Hze/J; https://www.jax.org/strain/007914; RRID:IMSR_JAX:007914) for subsequent visualization of cre-expressing cells.

Experimental mice $(\sim 2-5$ months of age $)$ were maintained in an environmentally controlled vivarium on a $12 \mathrm{~h}$ reversed light/dark cycle. Food and water were provided ad libitum until behavioral training commenced. During self-administration procedures, subjects were food restricted to $85-90 \%$ of their free-feeding bodyweight, and water was provided ad libitum. All procedures were conducted in strict accordance with the NIH Guide for the Care and Use of Laboratory Animals and were approved by the Institutional Animal Care and Use Committee of the University of California, Irvine. 


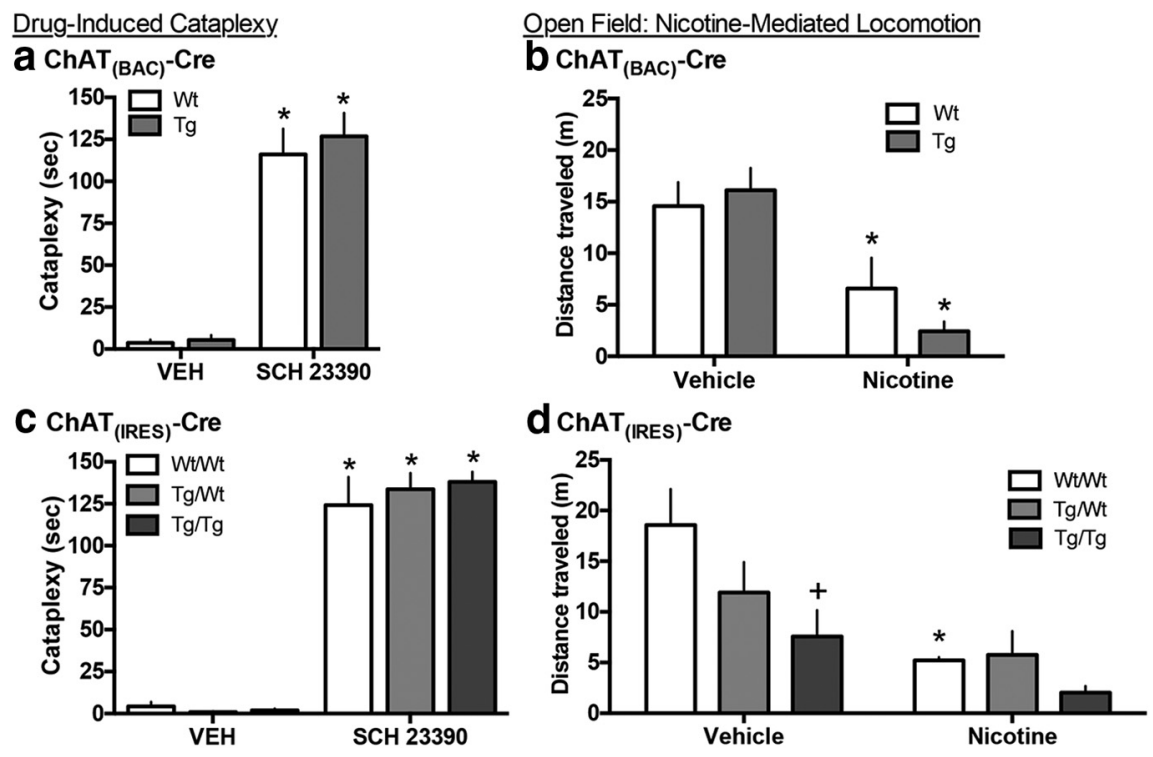

Figure 2. Drug-induced cataplexy and nicotine-mediated hypolocomotion in $\mathrm{ChAT}_{(\mathrm{BAC})}-\mathrm{Cre}$ and $\mathrm{ChAT}_{(\mathrm{IRES})}$ - $\mathrm{Cre}_{\mathrm{r}}$ mouse lines. $\mathrm{ChAT}_{(\mathrm{BAC})}$-Cre Wt and $\mathrm{ChAT}_{(\mathrm{BAC})}$-Cre Tg mice exhibited expected drug-mediated effects with $\mathrm{SCH} 23390$-induced immobility in the cataplexy bar assessment $(\boldsymbol{a} ; n=5-8$ per group), and nicotine-induced decrease in locomotor behavior $(\boldsymbol{b} ; n=5$ per group) compared with vehicle-injected controls. Similarly, the $\mathrm{ChAT}_{(\mathrm{IRES})}$ - (re mice of all genotypes exhibited SCH 23390-induced cataplexy ( $c ; n=4-8$ per group). Nicotine-induced hypolocomotion was also found in the $\mathrm{ChAT}_{(\text {IRES)}}$ - $\mathrm{Cre}$ Wt/Wt mice. However, the $\mathrm{ChAT}_{(\text {IRES) }}$-Cre Tg/Tg group exhibited an overall decreased locomotor behavior with vehicle, and no statistically significant decrease was observed following nicotine injection for both the $\mathrm{ChAT}_{\text {(IRES) }}-\mathrm{Cre} \mathrm{Tg} / \mathrm{Tg}$ and $\mathrm{ChAT}_{\text {(IRES)}}$ - $\mathrm{Cre} \mathrm{Tg} / \mathrm{Wt}$ groups (d; $n=5$ per group). ${ }^{*} p<0.05$ compared to respective vehicle-injected controls, and ${ }^{+} p<0.05$ compared with vehicle-injected ChAT ${ }_{\text {(IRES) }}-\mathrm{Cre} \mathrm{Wt} / \mathrm{Wt}$ group. Data represent mean \pm SEM.

\section{Genotyping}

Around $21 \mathrm{~d}$ of age, pups were weaned, and tails were clipped for genetic analysis. Subjects were genotyped with the following primers: $\mathrm{ChAT}_{(\mathrm{BAC})^{-}}$ Cre: 5'-GGT CTC CTT GTG GAG TGG GAG T-3' (Transgenic Forward), 5'-CGG CAA ACG GAC AGA AGC ATT-3' (Transgenic Reverse); ChAT $_{(\mathrm{IRES})}$-Cre: 5' -GTT TGC AGA AGC GGT GGG-3' (Wildtype Forward), 5'-CCT TCT ATC GCC TTC TTG ACG-3' (Mutant Forward), 5'-AGA TAG ATA ATG AGA GGC TC-3' (Common Reverse); Rosa-TdTomato 5'-AAG GGA GCT GCA GTG GAG TA-3' (Wild-type Forward), 5' -CCG AAA ATC TGT GGG AAG TC-3' (Wildtype Reverse), 5'-CTG TTC CTG TAC GGC ATG G-3' (Mutant Forward), 5'-GGC ATT AAA GCA GCG TAT CC-3' (Mutant Reverse).

\section{Drugs}

(-)-Nicotine hydrogen tartrate salt (MP Biomedical, catalog \#0215355491) was dissolved in $0.9 \%$ sterile saline, $\mathrm{pH}$ 7.4. Doses of nicotine refer to the free-base form. SCH 23390 (Tocris Bioscience, catalog \#0925) was dissolved in 0.9\% sterile saline. Subcutaneous and intraperitoneal injections were administered at a volume of $10 \mathrm{ml} / \mathrm{kg}$.

\section{Experimental design and statistical analyses}

Open-field assessment. Male and female mice were first examined for differences in general home-cage behavior and bodyweight $\left(\mathrm{ChAT}_{(\mathrm{BAC})^{-}}\right.$

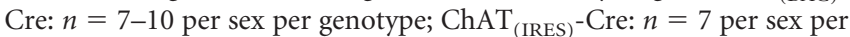
genotype). Thereafter, the first experimental cohort of male and female subjects $\left(\mathrm{ChAT}_{(\mathrm{BAC})} \text {-Cre: } n=9-10 \text { per sex per genotype; } \mathrm{ChAT}_{(\mathrm{IRES})}\right)^{-}$ Cre: $n=8-14$ per sex per genotype) was examined in an open-field chamber for generalized locomotor behavior during a 15 min test. The chamber was composed of Plexiglas $(35 \mathrm{~cm} \mathrm{~L} \times 35 \mathrm{~cm} \mathrm{~W} \times 31 \mathrm{~cm} \mathrm{H})$, and the center and outer-edge zones were designated with the ANY-maze computer software during video analysis. The chamber was enclosed within a black enclosure, and a shielded white light lamp was placed $\sim 90 \mathrm{~cm}$ above the apparatus for consistent lighting. Before testing, mice were habituated by handling for at least $5 \mathrm{~min}$ per day for $2 \mathrm{~d}$. After the baseline locomotor test, a subset of male mice were then examined for nicotine-mediated locomotor effects after a $\geq 24 \mathrm{~h}$ period; additional age-matched subjects for each group were added to this subset to provide sufficient numbers for testing $\left(\mathrm{ChAT}_{(\mathrm{BAC})^{-}}\right.$ Cre: $n=5$ per genotype; $\operatorname{ChAT}_{(\text {IRES) }}$-Cre: $n=$ 5 per genotype). The cages were placed in the room at least 30 min before testing for acclimation, and thereafter, mice were individually placed into the open field for a 15 min habituation period. Subjects were then injected subcutaneously with either $0.8 \mathrm{mg} / \mathrm{kg}$ nicotine or saline control and placed back into the home cage for $15 \mathrm{~min}$. Subjects were then put into the open-field apparatus for a 15 min test. Activity was recorded with a video camera and scored with ANY-maze software.

Elevated plus maze. A second cohort of male mice $\left(\mathrm{ChAT}_{(\mathrm{BAC})}\right.$-Cre: $n=13-14$ per genotype; $\mathrm{ChAT}_{\text {(IRES) }}$-Cre: $n=7-8$ per genotype) was examined for anxiety-related behavior in the elevated plus maze (EPM) during a $5 \mathrm{~min}$ test. The EPM was composed of 4 opaque gray runways $5 \mathrm{~cm}$ wide and $35 \mathrm{~cm}$ in length, which were elevated $40 \mathrm{~cm}$ from the floor. Two opposing closed runways had opaque walls $15 \mathrm{~cm}$ in height, whereas the other two opposing sides did not contain walls (open arms). A shielded lamp was placed $\sim 60 \mathrm{~cm}$ above the center of the maze for consistent lighting. Before testing, mice were habituated by handling for at least $5 \mathrm{~min}$ per day for $2 \mathrm{~d}$. On the test day, cages were placed in the room at least $30 \mathrm{~min}$ for acclimation. Subjects were all placed in the center portion of the elevated plus maze with their head facing into an open arm of the maze, and behavior was recorded for 5 min thereafter with a video camera. Behavior was scored with ANY-maze software, in which the animal's head was used as the designated point to quantify time in an arm in accordance with the ANY-maze software program settings.

Cataplexy assessment. A third cohort of male mice $\left(\mathrm{ChAT}_{(\mathrm{BAC})}{ }^{-C r e:}\right.$ $n=5-8$ per genotype; $\mathrm{ChAT}_{(\mathrm{IRES})}$-Cre: $n=4-8$ per genotype) was examined in the cataplexy bar test as described previously (Kharkwal et al., 2016). Mice were injected intraperitoneally with SCH 23390 (0.035 $\mathrm{mg} / \mathrm{kg}$ ), a dopamine D1 receptor antagonist, or saline vehicle $30 \mathrm{~min}$ before the test session. This lower dose of SCH 23390 was selected based previous findings demonstrating moderate effects in mice (Kharkwal et al., 2016). During testing, mice were placed with forepaws on a $0.5 \mathrm{~cm}$ diameter rod covered with nonslippery tape, which was suspended $5 \mathrm{~cm}$ above the bench. The test session was video recorded. The time spent immobile was measured across three consecutive trials, and the cutoff time for each trial was $2.5 \mathrm{~min}$. The mean of the three trials for each subject was used for data analysis.

Food and intravenous nicotine self-administration. A fourth cohort of male and female mice $\left(\mathrm{ChAT}_{(\mathrm{BAC})}\right.$-Cre: $n=4-10$ per sex per genotype; ChAT $_{\text {(IRES) }}$-Cre: $n=7-11$ per sex per genotype) was mildly food restricted to $85-90 \%$ of their free-feeding bodyweight and trained to press a lever in an operant chamber (Med Associates) for food pellets ( $20 \mathrm{mg}$; TestDiet) under a fixed-ratio 5, time out $20 \mathrm{~s}$ (FR5TO20 s) schedule of reinforcement. Once stable responding was achieved $(>25$ pellets per session across 3 subsequent sessions), male subjects were surgically catheterized as previously described (Fowler et al., 2011). Briefly, mice were anesthetized with an isoflurane (1-3\%)/oxygen vapor mixture and prepared with intravenous catheters. Catheters consisted of a $6 \mathrm{~cm}$ length of Silastic tubing fitted to guide cannula (Plastics One) bent at a curved right angle and encased in dental acrylic. The catheter tubing was passed subcutaneously from the animal's back to the right jugular vein, and a $1 \mathrm{~cm}$ length of the catheter tip was inserted into the vein and tied with surgical silk suture. Following the surgical procedure, animals were allowed $\geq 48 \mathrm{~h}$ to recover from surgery, then provided access to respond for food reward. Male subjects $\left(\mathrm{ChAT}_{(\mathrm{BAC})}-\mathrm{Cre}: n=5-6\right.$ per genotype; ChAT $_{\text {(IRES) }}$-Cre: $n=5-6$ per genotype) were then permitted to acquire intravenous nicotine self-administration during $1 \mathrm{~h}$ daily sessions, $6-7 \mathrm{~d}$ 
per week, at the standard training dose of nicotine $(0.03 \mathrm{mg} / \mathrm{kg} /$ infusion $)$. Based on low responding found in the $\mathrm{ChAT}_{(\mathrm{BAC})}$-Cre $\mathrm{Tg}$ mice at the $0.03 \mathrm{mg} / \mathrm{kg} /$ infusion training dose, an additional cohort of male mice $(n=14)$ was provided access to a lower dose of nicotine $(0.01 \mathrm{mg} / \mathrm{kg} /$ infusion $)$ as the initial training dose. Nicotine was delivered through tubing into the intravenous catheter by a Razel syringe pump (Med Associates). Each session was performed using two retractable levers ( 1 active, 1 inactive). Completion of the response criteria on the active lever resulted in the delivery of an intravenous nicotine infusion $(0.03 \mathrm{ml}$ infusion volume; FR5TO20 s schedule). Responses on the inactive lever were recorded but had no scheduled consequences. Catheters were flushed daily with physiological sterile saline solution $(0.9 \% \mathrm{w} / \mathrm{v})$ containing heparin $(100$ USP U/ml). Catheter integrity was tested with the ultra short-acting barbiturate anesthetic Brevital (methohexital sodium, Eli Lilly). To ascertain the dose-response function, male mice $\left(\mathrm{ChAT}_{(\mathrm{BAC})}\right.$-Cre: $n=7-10$ per genotype; $\mathrm{ChAT}_{\text {(IRES) }}$-Cre: $n=5-7$ per genotype) were then tested as described previously (Fowler and Kenny, 2011). Briefly, following an acquisition period of at least $7 \mathrm{~d}$ on the training dose $(0.03$ $\mathrm{mg} / \mathrm{kg} /$ infusion), the animals were presented with a different dose of nicotine for at least $5 \mathrm{~d}$, and the mean intake for the last three sessions was used for statistical analyses. In between each dose, subjects were returned to the 0.1 $\mathrm{mg} / \mathrm{kg} /$ infusion dose for $2 \mathrm{~d}$ or until intake returned to baseline levels. Subjects and their data were removed from the study if the catheter integrity was compromised as determined by visual leakage or Brevital assessment. Behavioral responses were automatically recorded by Med Associates software.

$R T-q P C R$. A fifth cohort of male mice from each genotype $\left(\mathrm{ChAT}_{(\mathrm{BAC})}{ }^{-}\right.$ Cre: $n=5$ per genotype; ChAT $_{\text {(IRES) }}$-Cre: $n=10-12$ per genotype) had their brain regions immediately microdissected, placed in a collection tube and flash frozen. All tissue was stored at $-80^{\circ} \mathrm{C}$ until further processing. RNA was extracted from homogenized tissue with Trizol reagent (Ambion Life Technologies) via the manufacturer's protocol. The quality of the RNA was determined by a NanoDrop 2000 spectrophotometer (ThermoFisher Scientific). For each sample, 100 ng of total RNA was reverse transcribed into cDNA with the iScript cDNA synthesis kit (BioRad Laboratories). Quantitative PCR was performed for cre recombinase (cre; Assay Mr00635245_cn, ThermoFisher Scientific) and the housekeeping gene, $\beta$-actin (ACTB; Assay Mm02619580_g1, ThermoFisher Scientific). TaqMan Universal Master Mix II with real time PCR gene expression assays were used according to the manufacturer's parameters (Applied Biosystems). Samples were tested in duplicate or triplicate and quantified with a CFX96 RT-qPCR system (Bio-Rad). Samples with CT values $>35$ cycles were considered outside of the range of inclusion, and thus, these samples were determined to exhibit no expression in the tissue of interest. Normalized gene expression was calculated by dividing the $2^{\Delta C T}$ values for each gene of interest by the corresponding $\beta$-actin value and multiplying by a factor of 100.

Protein expression analysis. Hippocampal ChAT, VAChT, and $\beta$-actin expression levels were evaluated with Western blot in a sixth cohort of mice; this cohort included male subjects from the EPM test and additional subjects were added to achieve sufficient samples for processing (ChAT Westerns: $\mathrm{ChAT}_{(\mathrm{BAC})}$-Cre, $n=13-15$ per genotype; $\mathrm{ChAT}_{(\mathrm{IRES})}{ }^{-}$ Cre, $n=8-12$ per genotype; VAChT Westerns: ChAT $_{(\mathrm{BAC})}-\mathrm{Cre}, n=$ $10-12$ per genotype; $\mathrm{ChAT}_{(\mathrm{IRES})}$-Cre, $n=5-15$ per genotype). Samples were run in duplicate or triplicate, dependent on the amount of protein available. Total protein concentrations were determined using the BCA Protein Assay (ThermoFisher Scientific). Samples of $30 \mu \mathrm{g}$ of protein were run with electrophoresis on $15 \%$ precast polyacrylamide gel. Proteins were transferred to nitrocellulose membranes (Bio-Rad). The membranes were blocked for $2 \mathrm{~h}$ at $4^{\circ} \mathrm{C}$ in blocking buffer (containing $5 \%$ BSA, $0.1 \%$ Tween 20, and $0.01 \mathrm{~m}$ tris-buffered saline) followed by primary antibody incubation against VAChT (goat polyclonal antibody, 1:5000 dilution; Santa Cruz Biotechnology, catalog \#sc-7717; RRID: AB_2301794), ChAT (goat polyclonal antibody, 1:1000 dilution; EMD Millipore, catalog \#AB144P; RRID:AB_2079751), or $\beta$-actin (mouse monoclonal antibody, 1:7500 dilution; Sigma-Aldrich, catalog \#A5316; RRID:AB_476743) overnight at $4^{\circ} \mathrm{C}$. The membranes were then incubated with HRP-conjugated donkey anti-goat or anti-mouse IgG secondary antibody (1:10,000 dilution; Jackson ImmunoResearch) for $2 \mathrm{~h}$ at room temperature. Membranes were imaged and analyzed via ChemiDoc XRS + system and software (Bio-Rad), and protein levels were determined by quantification of the band density for ChAT, VAChT, and $\beta$-actin. ChAT and VAChT values were normalized to $\beta$-actin expression. Cre protein expression was also analyzed, but similar bands were found in wild-type and cre-expressing tissue, indicating nonspecific reactivity of the primary antibodies; thus, data are not included. Crerecombinase antibodies tested included: mouse monoclonal (1:1000 dilution; Abcam, catalog \#ab24607; RRID:AB_448179), rabbit polyclonal (1:5000; Abcam, catalog \#ab188568), and rabbit polyclonal 69050-3 (1:10,000; Novagen/Sigma-Aldrich, catalog\# 69050-3; RRID: AB_10806983).

For immunofluorescence analysis, ChAT-Cre::ROSA ${ }^{265 o r}$-tdTomato male mice $\left(\mathrm{ChAT}_{(\mathrm{BAC})}-\mathrm{Cre}, n=4-5\right.$ per genotype; $\mathrm{ChAT}_{(\mathrm{IRES})}-\mathrm{Cre}, n=$ 4-5 per genotype) were anesthetized with ketamine-xylazine and 


\section{Intravenous Nicotine Self-Administration: $\mathrm{ChAT}_{(\mathrm{BAC})}{ }^{-\mathrm{Cre}}$}

\section{a}
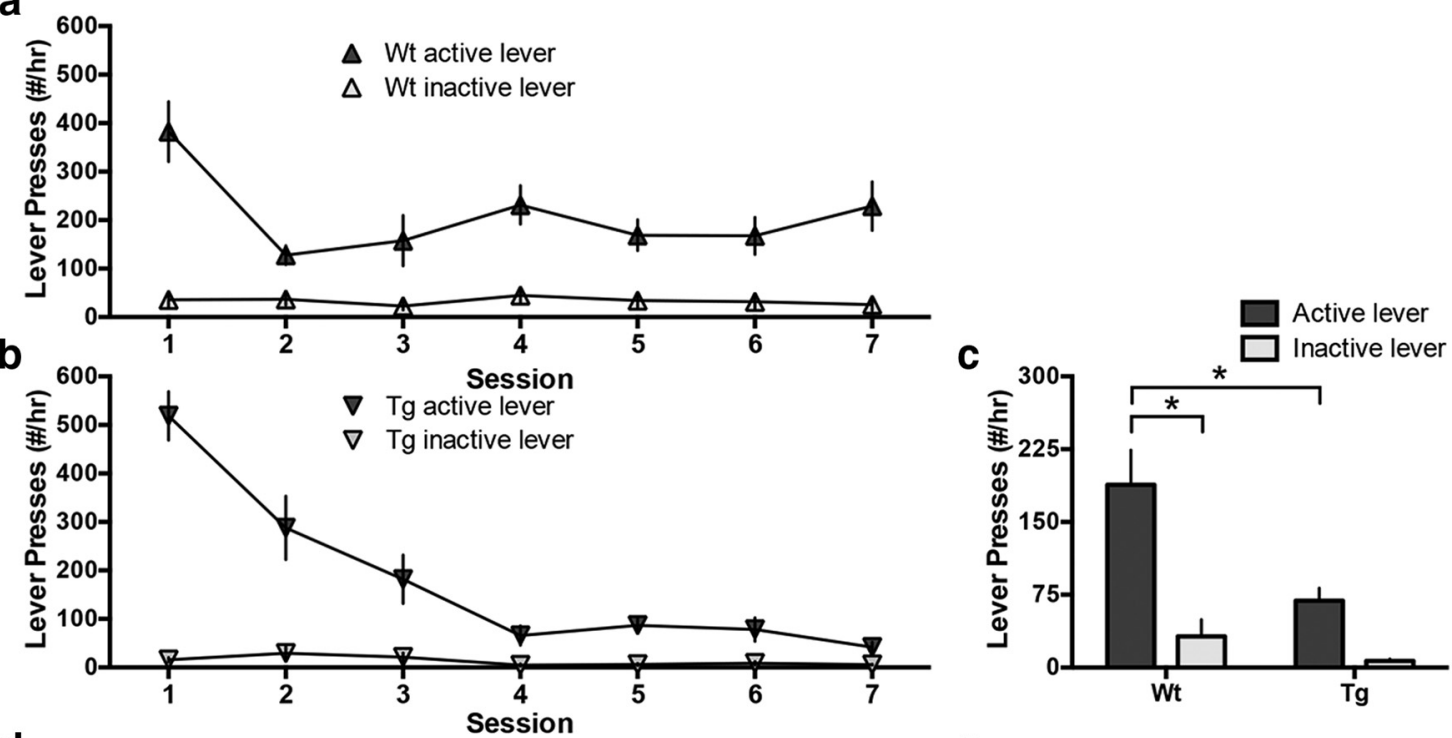

d
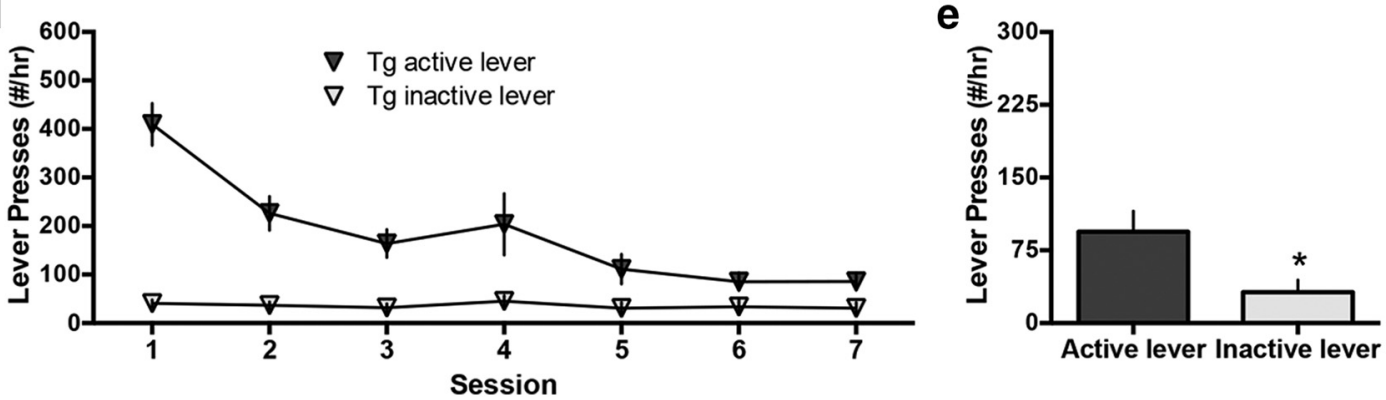

Figure 4. $\mathrm{ChAT}_{(\mathrm{BAC})}$-Cre Tg mice exhibit deficits in the acquisition of nicotine self-administration. $\mathrm{ChAT}_{(\mathrm{BAC})}$ - $\mathrm{Cre}$ mice $(n=5-6$ per group) were provided access to the standard training 0.03 $\mathrm{mg} / \mathrm{kg} /$ infusion dose during $1 \mathrm{~h}$ daily sessions; $\mathrm{ChAT}_{(\mathrm{BAC})}-\mathrm{Cre}_{\mathrm{Ct}}$ mice achieved a stable level of responding across sessions $(\boldsymbol{a})$, whereas $\mathrm{ChAT}_{(\mathrm{BAC})} \mathrm{Cre}^{\mathrm{Cg}}$ mice significantly attenuated their

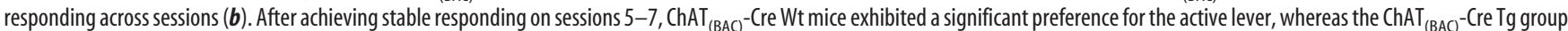

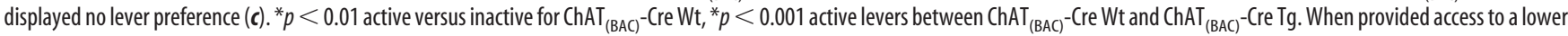
training dose of nicotine $\left(0.01 \mathrm{mg} / \mathrm{kg} /\right.$ infusion) during daily $1 \mathrm{~h}$ sessions, $\mathrm{ChAT}_{(\mathrm{BAC})}$-Cre Tg mice $(n=14$ per group) exhibited relatively more stable responding across later acquisition sessions (d) with statistically significant preference for the active lever $(\boldsymbol{e}) .{ }^{*} p<0.01$ compared with active lever. Data represent mean \pm SEM.

perfused through the ascending aorta with $0.9 \%$ physiological saline, followed by $4 \%$ paraformaldehyde in $0.1 \mathrm{M}$ PBS, $\mathrm{pH}$ 7.4. Thereafter, brains were removed and postfixed for $2 \mathrm{~h}$ in paraformaldehyde, followed by incubation in $30 \%$ sucrose for at least $72 \mathrm{~h}$. Sections were cut on a cryostat at $35 \mu \mathrm{m}$ thickness and stored in $0.1 \mathrm{M}$ PBS. Sections containing the medial septum and dorsal hippocampus were mounted on glass slides and coverslipped with Vectashield containing DAPI (Vector Laboratories). Slides were then examined with a Leica DM4000 fluorescence microscope with the same $20 \times$ magnification, gain, and exposure maintained for all imaging of each brain region.

Approach for unbiased data collection. Subjects were genotyped before experimental investigation and provided a subject ID number that did not denote group assignment. This information was retained in a secure database. The animals were then assigned to the experimenters on a cage-by-cage basis for experimental testing; since the mice were littermates, each cage consisted of subjects with varying genotypes (e.g., mice were not housed based on genotype). After all data were collected within each experiment by experimenters blinded to the testing condition, the results were sent to another investigator not involved in the experimental analysis for decoding and statistical analyses. Each behavior was scored by two blinded experimenters to provide further confidence in the findings. In the event that a drug injection was known to the experimenter performing the behavioral test, other blinded experimenters completed the data quantification/analysis. When possible, ANY-maze software was used to analyze the data to provide an additional level of objective behavioral assessment.
Statistical analyses. Data were analyzed by a $t$ test, one-way, two-way, or three-way ANOVA using GraphPad Prism or IBM SPSS software, as appropriate. Significant main or interaction effects were followed by Bonferroni or Sidak post hoc comparison with correction for multiple comparisons. The criterion for significance was set at $\alpha=0.05$.

\section{Results}

\section{General characteristics}

Mice were first examined for differences in general home-cage behavior and bodyweight. Subjects did not differ in any notable subjective measures (activity, grooming, appearance). When examined for bodyweight, the $\mathrm{ChAT}_{(\mathrm{BAC})}$-Cre wild-type $(\mathrm{Wt})$ and transgenic (Tg) mice exhibited similar free-feeding bodyweights [Wt: male $24.53 \pm 0.47$ (grams \pm SEM), female $20.19 \pm 0.65$; Tg: male $25.5 \pm 0.54$, female $20.07 \pm 0.81]$. A main effect was found with males weighing more than females, as expected (two-way ANOVA: Genotype: $F_{(1,33)}=0.44, p=0.514$; Sex: $F_{(1,33)}=53.65$, $p=0.000$; Interaction: $\left.F_{(1,33)}=0.70, p=0.411\right)$. Similarly, $\mathrm{ChAT}_{\text {(IRES) }}$-Cre wild-type $(\mathrm{Wt} / \mathrm{Wt})$, hemizygous $(\mathrm{Tg} / \mathrm{Wt})$, and transgenic $(\mathrm{Tg} / \mathrm{Tg})$ mice exhibited a similar pattern between groups (Wt/Wt: male $24.53 \pm 0.47$, female $20.19 \pm 0.65 ; \mathrm{Tg} / \mathrm{Wt}$ : male $26.63 \pm 1.27$, female $21.40 \pm 0.38$; $\mathrm{Tg} / \mathrm{Tg}$ : male $28.23 \pm$ 0.60 , female $20.37 \pm 0.46)$. A significant difference was found with males having a greater mean bodyweight compared with 
females (two-way ANOVA: Genotype: $F_{(2,42)}=1.06, p=0.356$; Sex: $F_{(1,42)}=$ 89.32, $p=0.000$; Interaction: $F_{(2,42)}=$ $1.20, p=0.312)$.

\section{Locomotor, cataplexy, and} anxiety-related behaviors

Baseline differences in locomotor activity in the open field were examined across genotypes (Fig. 1). Male and female $\mathrm{ChAT}_{(\mathrm{BAC})}$-Cre Wt and Tg mice did not significantly differ in distance traveled (Fig. 1a; two-way ANOVA: Genotype: $F_{(1,39)}=0.01, p=0.915$; Sex: $F_{(1,39)}=$ $0.16, p=0.696$; Interaction: $F_{(1,39)}=0.02$, $p=0.897)$ or time spent in the center area of the chamber (Fig. $1 b$; two-way ANOVA: Genotype: $F_{(1,39)}=1.07, p=$ 0.308 ; Sex: $F_{(1,39)}=0.063, p=0.803$; Interaction: $\left.F_{(1,39)}=0.16, p=0.688\right)$, suggesting similar exploratory behavior, generalized locomotion and anxietyrelated behavior. In contrast, differences were found with the $\mathrm{ChAT}_{\text {(IRES) }^{-} \text {-Cre Wt/ }}$ $\mathrm{Wt}, \mathrm{Tg} / \mathrm{Wt}$, and $\mathrm{Tg} / \mathrm{Tg}$ groups, in which the $\mathrm{Tg} / \mathrm{Tg}$ mice exhibited an overall attenuated locomotor activity as assessed by distance traveled (Fig. 1d; two-way ANOVA: Genotype: $F_{(2,65)}=19.61, p=$ 0.000 ; Sex: $F_{(1,65)}=0.27, p=0.608$; Interaction: $\left.F_{(2,65)}=2.13, p=0.128\right)$, but a main effect for sex or interaction were not found. Post hoc analysis revealed significantly decreased distance traveled for $\mathrm{Tg} / \mathrm{Tg}$ mice compared with both $\mathrm{Wt} / \mathrm{Wt}$ $(p<0.001)$ and $\mathrm{Tg} / \mathrm{Wt}(p<0.001)$ mice, but no difference was found between the $\mathrm{Wt} / \mathrm{Wt}$ and $\mathrm{Tg} / \mathrm{Wt}$ groups. ChAT (IRES) $^{-}$ Cre groups did not differ in center time (Fig. 1e; two-way ANOVA: Genotype: $F_{(2,65)}=2.04, p=0.139$; Sex: $F_{(1,65)}=$ $0.30, p=0.586$; Interaction: $F_{(2,65)}=0.75$, $p=0.476)$. Anxiety-associated behavior was further examined with the EPM. $\mathrm{ChAT}_{(\mathrm{BAC})}$-Cre Wt and Tg male mice did not differ in the time spent in the open arm of the EPM (Fig. 1c; unpaired $t$ test: $\left.t_{(25)}=0.04, p=0.969\right)$. Similarly, $\mathrm{ChAT}_{(\text {IRES)}}$-Cre male mice also did not differ in open arm time (Fig. 1f; one-way ANOVA: $\left.F_{(2,21)}=1.28, p=0.301\right)$. These findings further support the center time findings from the open field, with no phenotypic differences in anxiety-like behavior among the groups.

Next, male mice were examined for behavioral inhibition (cataplexy) following administration of SCH 23390, a selective D1 dopamine receptor antagonist. ChAT $_{(\mathrm{BAC})}$-Cre (Fig. $2 a$ ) and ChAT $_{\text {(IRES) }}$-Cre (Fig. 2c) mice exhibited similar behavioral inhibition with a statistically significant increase in cataplexy following drug treatment, but no main effect of genotype or interaction were found $\left(\mathrm{ChAT}_{(\mathrm{BAC})}\right.$-Cre, one-way ANOVA: Genotype: $F_{(1,22)}=0.33, p=0.574$; Drug: $F_{(1,22)}=114.2, p=0.000$; Interaction: $F_{(1,22)}=0.17, p=0.682 ; \mathrm{ChAT}_{(\mathrm{IRES})}$-Cre, two-way ANOVA: Genotype: $F_{(2,15)}=0.27, p=0.389$; Drug: $F_{(1,15)}=$
382.2, $p=0.000$; Interaction: $\left.F_{(2,15)}=0.65, p=0.538\right)$. To assess nicotine-mediated hypolocomotor responses, male mice were next challenged with nicotine $(0.8 \mathrm{mg} / \mathrm{kg})$ or vehicle injections and examined in the open field. Both the $\mathrm{ChAT}_{(\mathrm{BAC})}$-Cre Tg and Wt mice exhibited similar nicotine-induced hypolocomotion (Fig. $2 b$; two-way ANOVA: Genotype: $F_{(1,8)}=0.49, p=0.504$; Drug: $F_{(1,8)}=18.46, p=0.003$; Interaction: $F_{(1,8)}=2.33, p=$ $0.165)$. In contrast, genotype and nicotine main effect differences were found in the $\mathrm{ChAT}_{(\mathrm{IRES})}$-Cre mice (Fig. 2d; two-way ANOVA: Genotype: $F_{(2,24)}=4.44, p=0.023$; Drug: $F_{(1,24)}=$ $18.30, p=0.000$; Interaction: $\left.F_{(2,24)}=1.67, p=0.212\right)$. Post hoc analysis revealed a significant decrease in distance traveled in the $\mathrm{Tg} / \mathrm{Tg}$ mice following vehicle injection $(p<0.05$ compared with 

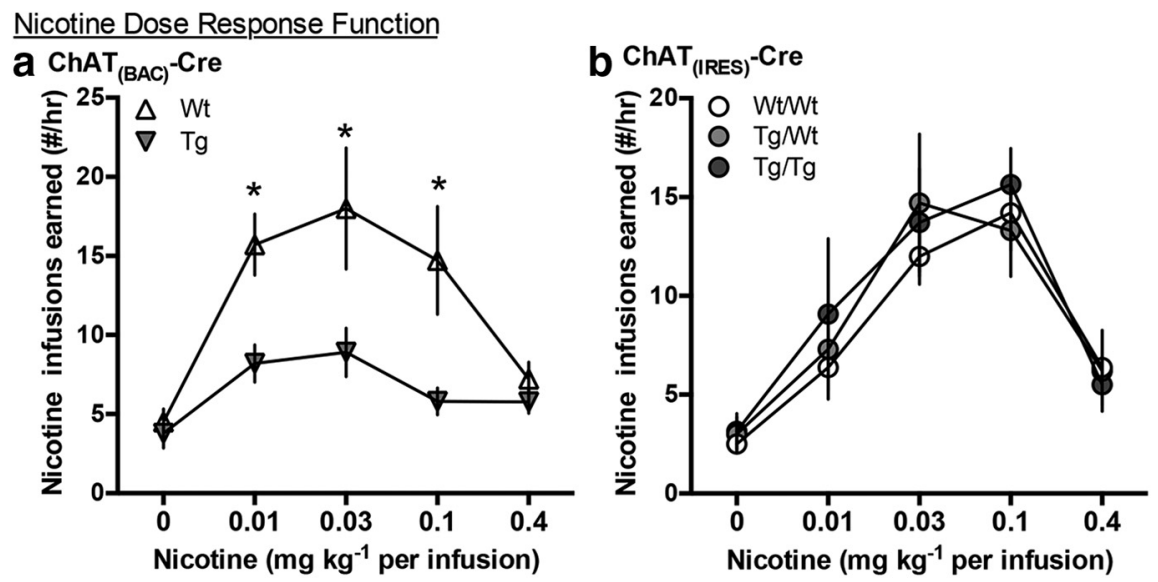

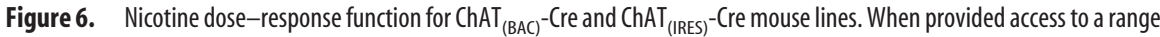
of doses during $1 \mathrm{~h}$ sessions, $\mathrm{ChAT}_{(\mathrm{BAC})}-\mathrm{Cre} \mathrm{Tg}$ mice ( $n=7-10$ per group) exhibited a flattened dose-response function (a), potentially indicative of increased nicotine aversion or decreased reinforcement for nicotine. In contrast, group differences were not present among the $\mathrm{ChAT}_{(\mathrm{IRES})}$ - Cre groups $\left(\boldsymbol{b} ; n=5-7\right.$ per group). ${ }^{*} p<0.05$ between $\mathrm{ChAT}_{(\mathrm{BAC})}-\mathrm{Cre} \mathrm{Wt}_{\mathrm{and}} \mathrm{ChAT}_{(\mathrm{BAC})}-\mathrm{Cre} \mathrm{Tg}$ at indicated dose. Data represent mean \pm SEM.

the Wt/Wt group), further confirming the overall lowered baseline level of activity in this group. Nicotine-induced hypolocomotion was found in the $\mathrm{Wt} / \mathrm{Wt}$ mice compared with their respective vehicle value $(p<0.001)$. However, both the $\mathrm{Tg} / \mathrm{Wt}$ and $\mathrm{Tg} / \mathrm{Tg}$ mice did not statistically differ in distance traveled following nicotine administration, which could potentially have been due to a floor effect for locomotor behavior and/or a decreased physiological response to nicotine.

\section{Learning- and memory-related behaviors}

To assess the ability to learn an operant response to obtain food reward, the mouse lines were examined for food selfadministration contingent on lever pressing behavior (Fig. 3). Both males and females were included in these assessments. ChAT $_{(\mathrm{BAC})}$-Cre mice exhibited a significant interaction across sessions for sex (Fig. 3a; three-way repeated-measures ANOVA (sphericity assumed): Genotype: $F_{(1,27)}=2.01, p=0.168$; Sex: $F_{(1,27)}=23.18, p=0.000$; Genotype $\times$ Sex Interaction: $F_{(1,27)}=$ 2.42, $p=0.131$; Session: $F_{(6,162)}=101.17, p=0.000$; Session $\times$ Genotype Interaction: $F_{(6,162)}=1.57, p=0.159$; Session $\times$ Sex Interaction: $F_{(6,162)}=6.33, p=0.000$; Session $\times$ Genotype $\times$ Sex Interaction: $\left.F_{(6,162)}=0.20, p=0.975\right)$. Whereas the groups exhibited similar acquisition during the initial training sessions, the female mice demonstrated an overall lower level of lever pressing for food pellets than males across days. For the $\mathrm{ChAT}_{(\mathrm{IRES})}$-Cre mice, the $\mathrm{Tg} / \mathrm{Tg}$ group appeared to require an increased number of sessions to achieve a similar level of responding as the $\mathrm{Wt} / \mathrm{Wt}$ mice (Fig. $3 b$; three-way repeated-measures ANOVA (sphericity assumed): Genotype: $F_{(2,43)}=4.63, p=0.015$; Sex: $F_{(1,43)}=6.02$, $p=0.018$; Genotype $\times$ Sex Interaction: $F_{(2,43)}=0.55, p=0.583$; Session: $F_{(6,258)}=95.99, p=0.000$; Session $\times$ Genotype Interaction: $F_{(12,258)}=2.30, p=0.009$; Session $\times$ Sex Interaction: $F_{(6,258)}=3.35, p=0.003$; Session $\times$ Genotype $\times$ Sex Interaction: $\left.F_{(12,258)}=0.92, p=0.527\right)$. Post hoc analysis revealed significantly decreased responding of the $\mathrm{Tg} / \mathrm{Tg}$ group compared with both the Tg/Wt $(p<0.05)$ and $\mathrm{Wt} / \mathrm{Wt}(p<0.01)$ groups. Of note, all subjects across groups achieved the set criteria for the number of food rewards obtained during the final three sessions ( $>25$ pellets/session; Fowler and Kenny, 2011), indicating that they all were physically capable of pressing the lever when fully trained and thus did not exhibit extensively gross learning/memory, attentional, or motor deficits.

\section{Nicotine self-administration}

Given the sex differences noted above with food training, male subjects were only examined for intravenous nicotine self-administration. ChAT $_{(\mathrm{BAC})}$-Cre mice were first examined for lever pressing behavior with the standard training dose of nicotine $(0.03 \mathrm{mg} / \mathrm{kg} /$ infusion; Fig. $4 a, b)$. $\mathrm{ChAT}_{(\mathrm{BAC})}$-Cre Tg mice attenuated their responding across nicotine sessions, whereas their Wt littermates sustained stable lever pressing for the active lever associated with nicotine infusions. After achieving stable responding on days 5-7 (Fig. 4c), Wt mice exhibited a significant preference for the active lever, whereas the Tg mice displayed no lever preference (two-way repeated-measures ANOVA: Genotype: $F_{(1,18)}=10.14, p=0.005$; Lever: $F_{(1,18)}=23.02, p=0.000$; Interaction: $F_{(1,18)}=4.35, p=$ $0.053)$. Post hoc tests revealed a significant difference between the $\mathrm{Wt}$ active and $\mathrm{Wt}$ inactive lever $(p<0.001)$, Wt active and Tg active lever $(p<0.01)$, and Wt active and Tg inactive lever $(p<0.001)$. No statistical difference was found between the $\mathrm{Tg}$ active and Tg inactive lever $(p>0.05)$. Given that the $\mathrm{ChAT}_{(\mathrm{BAC})}$-Cre Tg mice did not acquire stable intravenous nicotine self-administration behavior on the training dose, we hypothesized that they may be exhibiting an enhanced aversive response to nicotine. Thus, we next examined a separate cohort of $\mathrm{ChAT}_{(\mathrm{BAC})}$-Cre $\mathrm{Tg}$ mice with a lower training dose of nicotine $(0.01 \mathrm{mg} / \mathrm{kg} /$ infusion; Fig. $4 d$,e). After transitioning onto nicotine infusions, mice developed relatively more consistent lever-pressing behavior preferentially for the active lever (Fig. 4d). When these data were analyzed as the mean of the last three sessions, a significant difference was found between responding on the active and inactive lever (Fig. $4 e$; paired $t$ test: $t_{(13)}=3.51, p=0.004, R^{2}=$ 0.488 ), although the mean number of responses was still lower than that observed in the $\mathrm{Wt}$ mice on the training dose (Fig. $4 \mathrm{c}$ ).

$\mathrm{ChAT}_{(\text {IRES) }}$-Cre mice were next tested for nicotine selfadministration. Stable preference for the active, nicotine infusion-associated lever was found for the $\mathrm{Wt} / \mathrm{Wt}, \mathrm{Tg} / \mathrm{Wt}$, and $\mathrm{Tg} / \mathrm{Tg}$ mice across sessions on the standard $0.03 \mathrm{mg} / \mathrm{kg} /$ infusion training dose of nicotine (Fig. $5 a-c$, respectively). When data were examined across the last $3 \mathrm{~d}$ of acquisition, all groups exhibited significantly increased responding on the active lever, with no differences across groups (Fig. 5d; two-way repeatedmeasures ANOVA: Genotype: $F_{(2,28)}=0.27, p=0.764$; Lever: $F_{(1,28)}=29.11, p=0.000$; Interaction: $\left.F_{(1,28)}=0.02, p=0.984\right)$.

Finally, both mouse lines were examined for intravenous nicotine self-administration across a range of doses to assess the dose-response function (Fig. 6). Whereas the $\mathrm{ChAT}_{(\mathrm{BAC})}$-Cre $\mathrm{Wt}$ mice exhibited a dose-response function similar to that demonstrated for mice on a C57BL/6J background (Fowler and Kenny, 2011), the $\mathrm{ChAT}_{(\mathrm{BAC})}$-Cre Tg mice exhibited a flattened and lowered dose-response function (Fig. $6 a$; two-way repeatedmeasures ANOVA: Genotype: $F_{(1,15)}=11.56, p=0.004$, Dose: $F_{(4,60)}=14.22, p=0.000$, Interaction: $\left.F_{(4,60)}=4.05, p=0.006\right)$. Post hoc analysis revealed significant genotype differences at the lower and moderate levels of nicotine, including the $0.01(p<$ $0.05), 0.03(p<0.01)$, and $0.1(p<0.01)$ doses. It should also be 

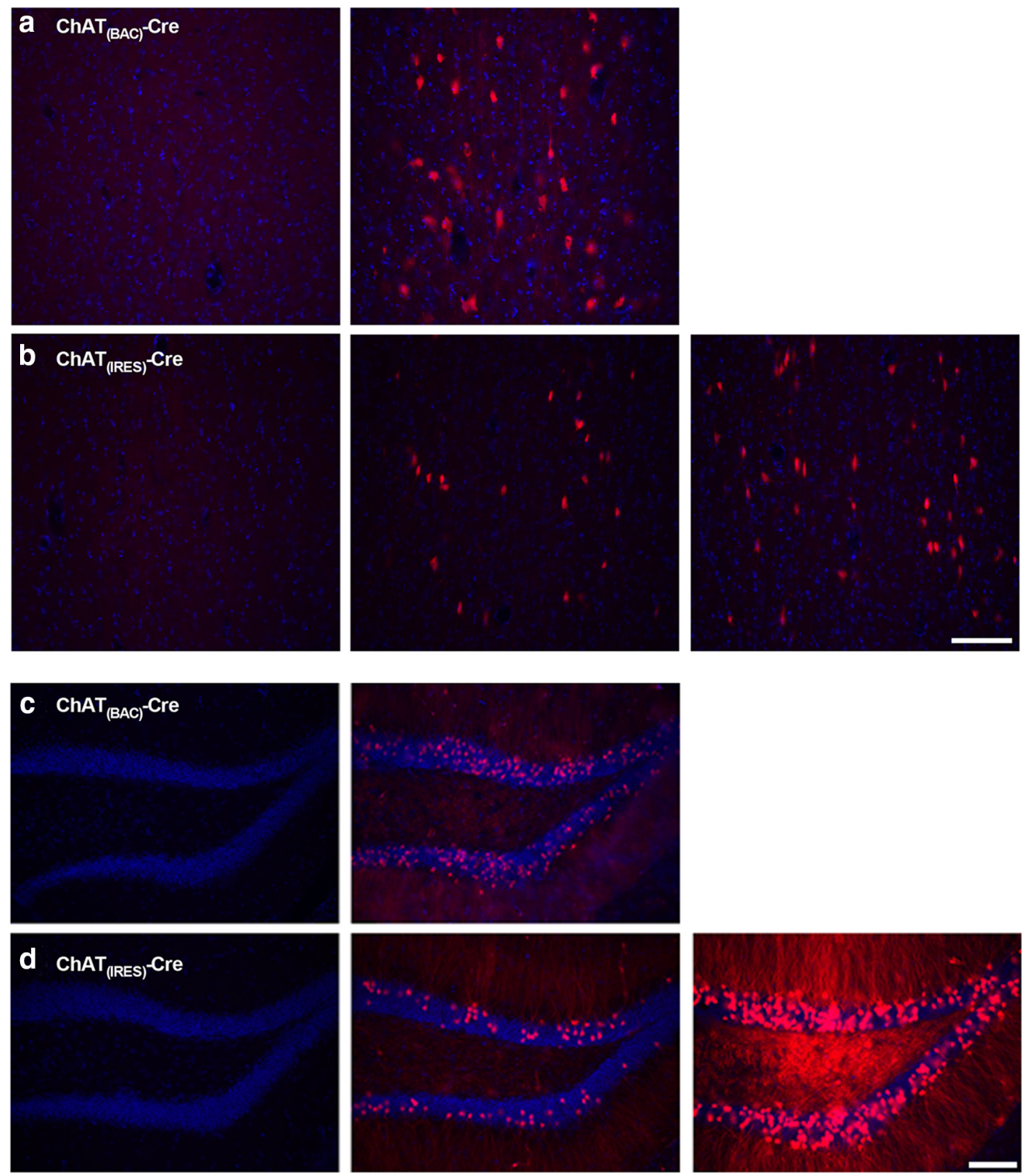

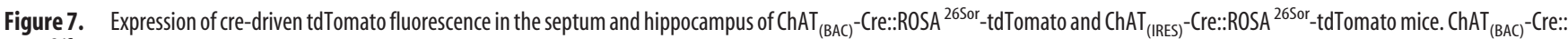
ROSA ${ }^{2650}$-tdTomato Tg mice exhibited moderate expression levels of td-Tomato fluorescence, indicative of cre expression, in both the septum ( $\boldsymbol{a}$, right) and hippocampus (c, right) compared with

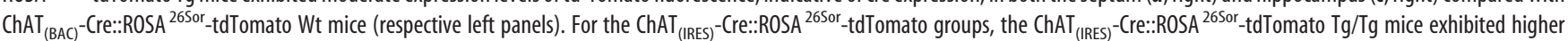

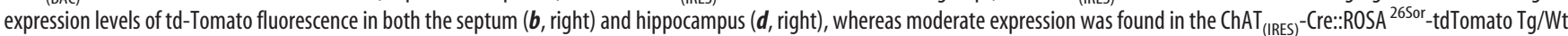

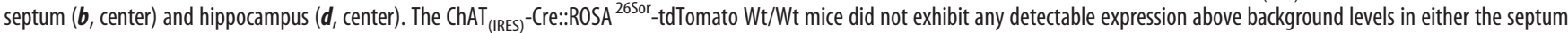
(b, left) or hippocampus (d, left). Red, tdTomato; Blue, DAPI. Scale bars: septum, $50 \mu \mathrm{m}$; hippocampus, $100 \mu \mathrm{m}$.

noted that the groups did not differ at the saline level of responding, indicating a similar overall baseline level of lever pressing activity. In contrast, $\mathrm{ChAT}_{(\mathrm{IRES})}-\mathrm{Cre} \mathrm{Wt} / \mathrm{Wt}, \mathrm{Tg} / \mathrm{Wt}$, and $\mathrm{Tg} / \mathrm{Tg}$ mice did not differ in their responses across doses (Fig. $6 b$; twoway repeated-measures ANOVA: Genotype: $F_{(2,13)}=0.07, p=$ 0.934 ; Dose: $F_{(4,52)}=20.15, p=0.000$; Interaction: $F_{(8,52)}=0.25$, $p=0.978$ ), with mice exhibiting a typical dose-response function with statistically significant preference for the 0.03 and $0.1 \mathrm{mg} /$ $\mathrm{kg} /$ infusion doses of nicotine compared with saline in post hoc analyses $(p<0.05)$.

\section{Cre expression in the brain}

To examine cre expression levels across genotypes, each mouse line was crossed with reporter mice expressing floxed tdTomato. This strategy allowed for the selective expression of red fluorescence in brain cells expressing cre under the ChAT promotor. The medial septum and hippocampus, brain regions implicated in cholinergic function, learning, and memory, and nicotine's actions, were examined under identical microscopy conditions. ChAT $_{(\mathrm{BAC})}$-Cre:: ROSA $^{265 \text { or }}$-tdTomato Tg mice exhibited moderately high levels of cre expression in both the septum and hip- 

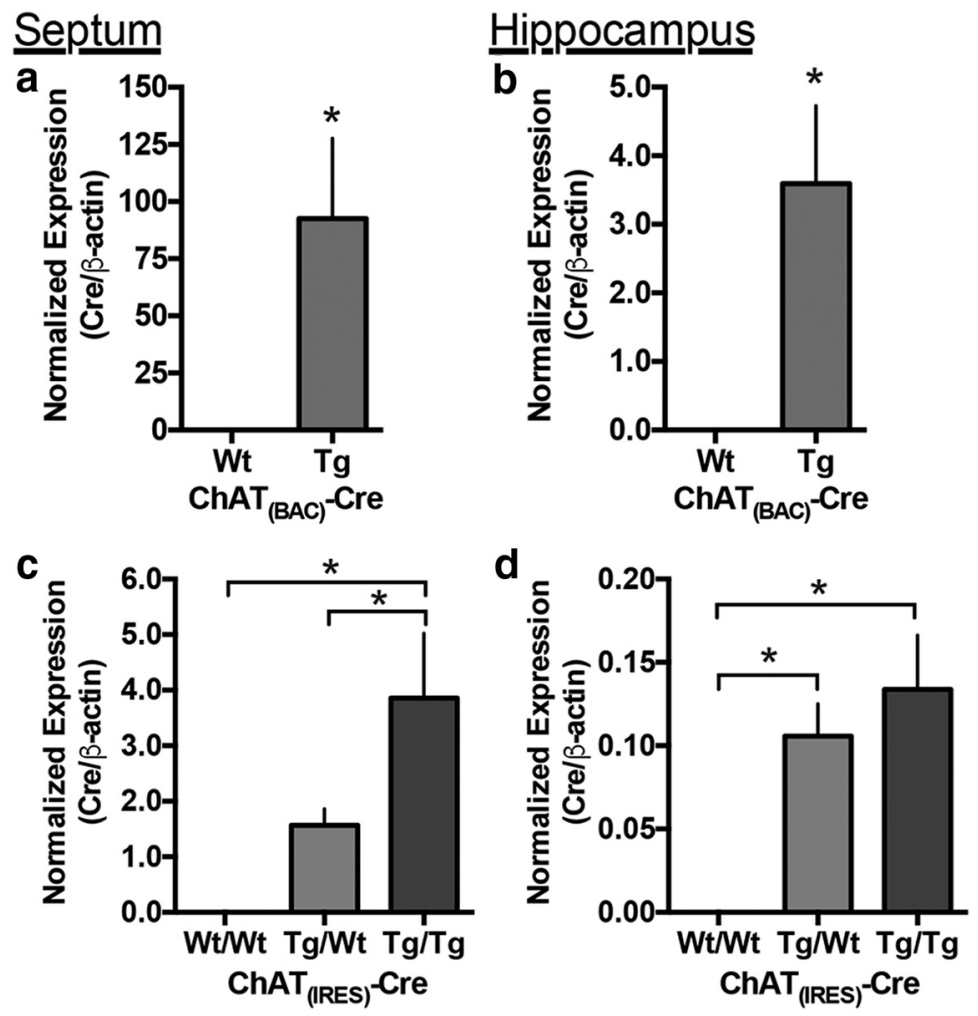

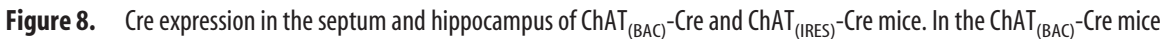
( $n=5$ per brain region per group), expression of cre was detected in both the septum $(\boldsymbol{a})$ and hippocampus $(\boldsymbol{b})$ of $\left.\mathrm{ChAT}_{(\mathrm{BAC})}\right)^{-\mathrm{Cre}}$ $\mathrm{Tg}$, but not $\mathrm{ChAT}_{(\mathrm{BAC})}-\mathrm{Cre} \mathrm{Wt}_{\text {, mice. }}{ }^{*} p<0.05$. In the $\left.\mathrm{ChAT}_{(\mathrm{IRES})}\right)^{-}$- $r e$ mice $(n=10-12$ per brain region per genotype), significant differences in cre expression were found between groups in the septum $(\boldsymbol{c})$, with a statistically significant increase in the ChAT ${ }_{(\mathbb{R E S S})^{-}}$

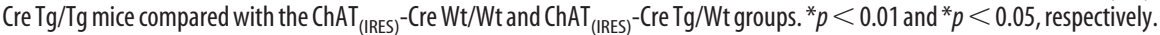
In the hippocampus $(\boldsymbol{d})$, differences between groups were also documented with a significant increase in expression for both the

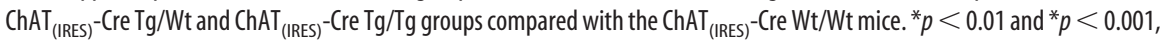
respectively. Data represent mean \pm SEM.

pocampus, as evidenced by tdTomato fluorescence, whereas no detectable expression was found in $\mathrm{ChAT}_{(\mathrm{BAC})}$-Cre Wt littermates positive for the ROSA ${ }^{26 S o r}$-tdTomato gene insert (Fig. $7 a, c)$. ChAT (IRES $_{\text {-Cre::ROSA }}{ }^{26 S o r}$-tdTomato $\mathrm{Tg} / \mathrm{Tg}$ mice exhibited very high levels of cre expression in both the septum and hippocampus (Fig. 7b,d). ChAT (IRES) -Cre::ROSA ${ }^{26 S o r}$-tdTomato $\mathrm{Tg} / \mathrm{Wt}$ mice exhibited an intermediate level of expression in these brain regions, whereas no detectable expression was found in mice lacking the $\mathrm{ChAT}_{\text {(IRES) }}$-Cre transgene (e.g., Wt/Wt littermates of $\mathrm{ChAT}_{(\mathrm{IRES})}$-Cre with the ROSA ${ }^{26 \mathrm{Sor}}$-tdTomato gene insert; Fig. $7 b, d)$.

To further validate the level of cre expression in the brain, brain tissue derived from $\mathrm{ChAT}_{(\mathrm{BAC})}-\mathrm{Cre}$ and $\mathrm{ChAT}_{(\mathrm{IRES})}-\mathrm{Cre}$ mice were examined for cre expression with RT-qPCR. In the septum and hippocampus of $\mathrm{ChAT}_{(\mathrm{BAC})}$-Cre mice, expression of cre was detected in the Tg, but not the Wt, brain tissue [Fig. $8 a, b$; unpaired $t$ test: $t_{(8)}=2.64, p=0.030, R^{2}=0.465$ (septum); unpaired $t$ test: $t_{(8)}=3.16, p=0.013, R^{2}=0.556$ (hippocampus)]. In the ChAT (IRES) -Cre mice, significant differences in cre expression were found between groups in the septum (Fig. $8 c$; one-way ANOVA: $\left.F_{(2,32)}=6.42, p=0.005, R^{2}=0.307\right)$. The post hoc test revealed a statistically significant increase in the $\mathrm{Tg} / \mathrm{Tg}$ mice compared with the $\mathrm{Wt} / \mathrm{Wt}$ and $\mathrm{Tg} / \mathrm{Wt}$ groups $(p<0.01$ and $p<0.05$, respectively). In the hippocampus, similar differences between groups were also documented (Fig. $8 d$; one-way ANOVA: $\left.F_{(2,30)}=10.47, p=0.000, R^{2}=0.437\right)$. Post hoc analyses revealed a significant increase in expression for both the
$\mathrm{Tg} / \mathrm{Wt}$ and $\mathrm{Tg} / \mathrm{Tg}$ groups compared with the $\mathrm{Wt} / \mathrm{Wt}$ mice $(p<0.01$ and $p<0.001$, respectively).

\section{Protein expression of VAChT and ChAT in the hippocampus}

Given that the hippocampus receives dense innervation of axonal projections from cholinergic brain regions, including the medial septum, we next examined for altered protein expression of VAChT and ChAT, both of which are enriched in the cholinergic presynaptic terminals in the hippocampus (Frotscher and Léránth, 1985; Gilmor et al., 1996; Schäfer et al., 1998). Western analyses revealed that the $\mathrm{ChAT}_{(\mathrm{BAC})}-\mathrm{Cre} \mathrm{Tg}$ mice had significantly increased VAChT expression compared with Wt littermates (Fig. 9a; unpaired $t$ test: $\left.t_{(20)}=1.97, p=0.032, R^{2}=0.162\right)$, whereas differences were not found between $\mathrm{ChAT}_{\text {(IRES) }}$-Cre groups (Fig. 9b; one-way ANOVA: $F_{(2,29)}=1.26, p=$ $0.300)$. Differences in protein expression of ChAT paralleled the differences found with VAChT for the $\mathrm{ChAT}_{(\mathrm{BAC})}$ Cre mice, with a significant increase in ChAT expression in Tg mice compared with Wt littermates (Fig. $9 c$; unpaired $t$ test: $\left.t_{(26)}=5.50, p=0.000, R^{2}=0.537\right)$. Unexpectedly, significantly decreased ChAT protein expression was found in the $\mathrm{ChAT}_{(\mathrm{IRES})}-\mathrm{Cre} \mathrm{Tg} / \mathrm{Tg}$ mice compared with both the Tg/Wt and $\mathrm{Wt} / \mathrm{Wt}$ mice (Fig. $9 d$; one-way ANOVA: $F_{(2,28)}=$ $\left.32.11, p=0.000, R^{2}=0.696\right)$.

\section{Discussion}

In the current studies, significant differences in baseline and nicotine-mediated behavioral profiles were found in two different ChAT-Cre transgenic mouse lines. These behavioral differences were paralleled by altered expression of cholinergic signaling factors. Specifically, whereas the $\mathrm{ChAT}_{(\mathrm{BAC})}$-Cre transgenic $(\mathrm{Tg})$, and wild-type $(\mathrm{Wt})$ mice did not differ in generalized locomotor, anxiety-related behavior, nicotine-induced hypolocomotion, drug-induced cataplexy, or operant food training, behavioral differences were found with intravenous nicotine selfadministration, in which the $\mathrm{ChAT}_{(\mathrm{BAC})}-\mathrm{Cre} \mathrm{Tg}$ mice exhibited a lowered and flattened dose-response function compared with Wt littermates. In contrast, $\mathrm{ChAT}_{(\mathrm{IRES})}$-Cre transgenic $(\mathrm{Tg} / \mathrm{Tg})$ mice exhibited decreased locomotor behavior, attenuated operant food training, and resistance to nicotine-induced hypolocomotion, but no difference in intravenous nicotine self-administration or drug-induced cataplexy, compared with wild-type $(\mathrm{Wt} / \mathrm{Wt})$ and hemizygous $(\mathrm{Tg} / \mathrm{Wt})$ littermates. Finally, altered expression of cre, VAChT, and ChAT were documented, evidence which provides a mechanistic basis for the phenotypes exhibited.

\section{Considerations based on method of genetic manipulation}

In generating the $\mathrm{ChAT}_{(\mathrm{BAC})}$-Cre line, multiple copies of the construct were randomly integrated into genomic DNA to target cre expression GENSAT, 2017 (Ting and Feng, 2014). More recently, novel approaches have been developed for next generation BAC 
clones, which have been designed to prevent undesirable gene overexpression (Ting and Feng, 2014). However, the BAC clone in the currently available ChAT-Cre lines contains several other genes, including Ogdhl, 1700024G13Rik, Slc18a3, and Ercc6. Thus, it is perhaps not surprising that the mice were found to be hypercholinergic with increased expression of VAChT, which is the product of the Slc18a3 gene. The increased cholinergic tone may further explain the decrease in nicotine self-administration found in the $\mathrm{ChAT}_{(\mathrm{BAC})}$-Cre Tg mice, which is indicative of either increased nicotine aversion and/or decreased reinforcement. Importantly, it should also be noted that this same BAC ID is found in other $\mathrm{ChAT}_{(\mathrm{BAC})}$-Cre mouse lines (GM24 and GM53) and the ChAT-Cre rat line (Gong et al., 2007; Witten et al., 2011; Ting and Feng, 2014). Also, the BAC clone insert for the ChAT-EGFP reporter and channelrhodopsin ChAT lines similarly contains a copy of the VAChT gene (Gong et al., 2003; Tallini et al., 2006; Zhao et al., 2011; Ting and Feng, 2014). Therefore, differences in behavior and cholinergic tone would be expected in all of these transgenic rat and mouse lines consistent with that observed in the $\mathrm{ChAT}_{(\mathrm{BAC})}$-Cre mice in the current study.

For the $\mathrm{ChAT}_{(\mathrm{IRES})}$-Cre mouse line, the IRES-Cre sequence was inserted downstream of the stop codon of the ChAT gene promotor (Rossi et al., 2011), which would be expected to result in unaltered VAChT or ChAT gene expression. Unexpectedly, we found differences in baseline behavior and decreased ChAT expression in the transgenic mice that contain two copies of the IRES-Cre insert (Tg/Tg genotype). While unexpected, it should be noted that a similar effect on dopamine transporter (DAT) protein expression was found in DAT-Cre Tg/Tg mice generated with the IRES method (Bäckman et al., 2006). While the documented decrease in ChAT expression in our studies may mediate some of the noted behavioral effects, the genetic manipulation itself is unlikely to have introduced these effects given the location of the gene insert. Therefore, it is more likely that overexpression of cre induced altered neuronal signaling and/or toxicity-related effects (Schmidt-Supprian and Rajewsky, 2007; Harno et al., 2013), which could have subsequently led to the decreased ChAT protein expression through either a negative feedback mechanism or perhaps disrupted protein synthesis. Indeed, cre overexpression has been previously reported to result in altered behavioral phenotypes in mouse models with other gene promoters, such as Nestin, Emx1, and Dlx5/6 (Schmidt et al., 2000; Schmidt-Supprian and Rajewsky, 2007; Harno et al., 2013; Kim et al., 2013; Giusti et al., 2014). Thus, in experimental studies, the potentially negative effects of cre alone could be due to the level of cre expression, cell-type specificity for vulnerability to cre-mediated toxicity, and/or unexpected effects based on
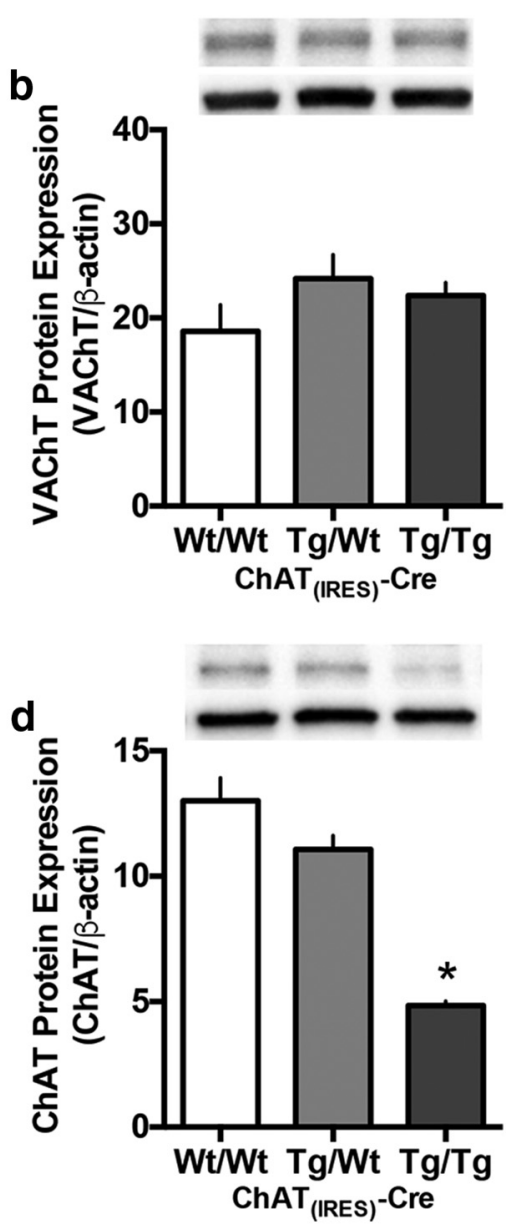

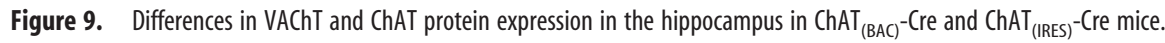
VAChT protein expression was significantly increased in $\mathrm{ChAT}_{(\mathrm{BAC})}$-Cre $\mathrm{Tg}$ mice compared with $\mathrm{ChAT}_{(\mathrm{BAC})}-\mathrm{Cre} \mathrm{Wt}_{\mathrm{C}}$ controls as visualized with Western blot (top, VAChT; bottom, $\beta$ actin) and density quantification ( $\boldsymbol{a} ; n=10-12$ per group). In contrast, group mice with Western blot visualization (top ChAT· bottom Bactin) and subsequent density quantification ( $c \cdot n=13-15$ pergroup).

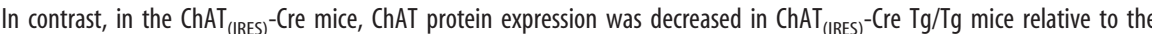

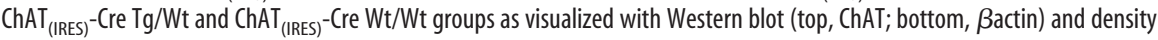
quantification ( $\boldsymbol{d} ; n=8-12$ per group). ${ }^{*} p<0.05$.

founder line crosses to generate double or triple transgenic subjects. For instance, in another study, the $\mathrm{ChAT}_{(\mathrm{IRES})}$-Cre line was crossed to either (Ai32)ChR2-YFP or (Ai35)Arch-GFP mice, and mice were maintained as full $\mathrm{Tg} / \mathrm{Tg} \mathrm{ChAT}_{\text {(IRES) }}$-Cre across further generations (Hedrick et al., 2016). Under these conditions, nonspecific expression of the optogenetic proteins were noted (Hedrick et al., 2016), which may suggest either ectopic expression of the opsin with this double line cross, or alternatively, developmental ChAT expression induced cre levels in this cell population that remained into adulthood. Although we did not note any overt ectopic expression in the current studies, this was not systematically examined in a cell-type-specific manner, and the expression patterns found in cell bodies of the hippocampus have been previously reported in a recent study (Yi et al., 2015). Interestingly, in the current study, a decrease in ChAT protein expression was paralleled by an increase in cre-driven tdTomato expression in the full $\mathrm{Tg} / \mathrm{Tg} \mathrm{ChAT}_{(\mathrm{IRES})}$-Cre::ROSA ${ }^{26 \mathrm{Sor}_{-}}$ tdTomato mice. Although these findings may initially appear contradictory, the expression of tdTomato is dependent on cre levels, rather than ChAT expression. As such, the increased inten- 
sity of tdTomato fluorescence in these mice likely reflects expression due to two copies of the Cre gene insert in the $\mathrm{Tg} / \mathrm{Tg}$ genome, which was further confirmed by the cre RT-qPCR data. This is an important point as inferences are often made between reporter fluorescence expression and promotor gene protein levels, leading to conclusions that may not be valid based on the cre-driver line used.

\section{Relevance of findings for nicotine reinforcement}

$\left.\mathrm{ChAT}_{(\mathrm{BAC})}\right)^{-C r e} \mathrm{Tg}$ mice exhibited no difference in nicotinemediated hypolocomotion compared with Wt littermates, but did display a significant attenuation of intravenous nicotine selfadministration across the dose-response function. In contrast, the $\mathrm{ChAT}_{(\mathrm{IRES})}-\mathrm{Cre} \mathrm{Tg} / \mathrm{Tg}$ and $\mathrm{Tg} / \mathrm{Wt}$ mice exhibited a deficit in nicotine-mediated hypolocomotion, but no differences in intravenous nicotine self-administration. Although the locomotor paradigm is often used to assess the behavioral effects of drugs and findings are often inferred to drug-taking behavior, the intravenous self-administration procedure is thought to provide higher translational relevance to drug taking behaviors in humans. As such, the hypercholinergic state induced in the $\mathrm{ChAT}_{(\mathrm{BAC})}$-Cre $\mathrm{Tg}$ mice appears to have led to substantially decreased volitional nicotine intake, a finding that provides important insight into the potential impact of increased baseline cholinergic tone on nicotine reinforcement. Second, it is also important to consider genetics of the background strain. For instance, it has been demonstrated that differential anxiety-related responses or drug-taking behaviors can be found dependent on the genetic background (Tarantino and Bucan, 2000; Võikar et al., 2001; Cervantes et al., 2013); in the current studies, all subjects from both of the lines were on a C57BL/6J background. Finally, we did find that the $\mathrm{ChAT}_{\text {(IRES) }}-\mathrm{Cre} \mathrm{Tg} / \mathrm{Tg}$ mice required an additional number of sessions to achieve maximal level of responding for food reward, which may have been due to motor-related effects given the differences found in baseline locomotor activity. However, it should be noted that all groups were capable of achieving a similar number of maximal responses for food. Moreover, the $\mathrm{ChAT}_{\text {(IRES) }}$-Cre mice exhibited no difference in responding for nicotine infusions. Together, these data indicate that baseline motor deficits could be overcome with training and/or a higher motivational drive to achieve the specific reward.

\section{Conclusions}

Given the intricacy of motivational systems that regulate complex behaviors, such as drug dependence, disentangling the limitations of technological advances to understand endogenous signaling mechanisms remains a challenge for scientists across fields. The current findings provide evidence that transgenic $\mathrm{ChAT}_{(\mathrm{BAC})}-\mathrm{Cre}$ and $\mathrm{ChAT}_{\text {(IRES) }}$-Cre mice exhibit altered cholinergic function, which was reflected in differential baseline behaviors and/or responsively to nicotine. As such, investigations with these mice should proceed with caution and in consideration of these factors. Given that the $\mathrm{ChAT}_{(\mathrm{IRES})}-\mathrm{Cre} \mathrm{Tg} / \mathrm{Wt}$ mice were similar to Wt/Wt controls in the vast majority of measures, utilization of these mice in future studies may yield data with greatest relevance to endogenous signaling conditions.

\section{References}

Bäckman CM, Malik N, Zhang Y, Shan L, Grinberg A, Hoffer BJ, Westphal H, Tomac AC (2006) Characterization of a mouse strain expressing cre recombinase from the $3^{\prime}$ untranslated region of the dopamine transporter locus. Genesis 44:383-390. CrossRef Medline

Bian Q, Belmont AS (2010) BAC TG-EMBED: one-step method for high- level, copy-number-dependent, position-independent transgene expression. Nucleic Acids Res 38:e127. CrossRef Medline

Caggiano V, Cheung VC, Bizzi E (2016) An optogenetic demonstration of motor modularity in the mammalian spinal cord. Sci Rep 6:35185. CrossRef Medline

Cervantes MC, Laughlin RE, Jentsch JD (2013) Cocaine self-administration behavior in inbred mouse lines segregating different capacities for inhibitory control. Psychopharmacology (Berl) 229:515-525. CrossRef Medline

Crittenden JR, Lacey CJ, Lee T, Bowden HA, Graybiel AM (2014) Severe drug-induced repetitive behaviors and striatal overexpression of VAChT in ChAT-ChR2-EYFP BAC transgenic mice. Front Neural Circuits 8:57. CrossRef Medline

Fowler CD, Kenny PJ (2011) Intravenous nicotine self-administration and cue-induced reinstatement in mice: effects of nicotine dose, rate of drug infusion and prior instrumental training. Neuropharmacology 61:687698. CrossRef Medline

Fowler CD, Kenny PJ (2012) Utility of genetically modified mice for understanding the neurobiology of substance use disorders. Hum Genet 131: 941-957. CrossRef Medline

Fowler CD, Lu Q, Johnson PM, Marks MJ, Kenny PJ (2011) Habenular alpha5 nicotinic receptor subunit signalling controls nicotine intake. Nature 471:597-601. CrossRef Medline

Frotscher M, Léránth C (1985) Cholinergic innervation of the rat hippocampus as revealed by choline acetyltransferase immunocytochemistry: a combined light and electron microscopic study. J Comp Neurol 239:237-246. CrossRef Medline

GENSAT (2017) The Gene Expression Nervous System Atlas (GENSAT) Project, NINDS contracts N01NS02331 and HHSN271200723701C to the Rockefeller University (New York). http://www.gensat.org/cre.jsp.

Gilmor ML, Nash NR, Roghani A, Edwards RH, Yi H, Hersch SM, Levey AI (1996) Expression of the putative vesicular acetylcholine transporter in rat brain and localization in cholinergic synaptic vesicles. J Neurosci 16: 2179-2190. Medline

Giusti SA, Vercelli CA, Vogl AM, Kolarz AW, Pino NS, Deussing JM, Refojo D (2014) Behavioral phenotyping of nestin-cre mice: implications for genetic mouse models of psychiatric disorders. J Psychiatr Res 55:87-95. CrossRef Medline

Gong S, Zheng C, Doughty ML, Losos K, Didkovsky N, Schambra UB, Nowak NJ, Joyner A, Leblanc G, Hatten ME, Heintz N (2003) A gene expression atlas of the central nervous system based on bacterial artificial chromosomes. Nature 425:917-925. CrossRef Medline

Gong S, Doughty M, Harbaugh CR, Cummins A, Hatten ME, Heintz N, Gerfen CR (2007) Targeting cre recombinase to specific neuron populations with bacterial artificial chromosome constructs. J Neurosci 27: 9817-9823. CrossRef Medline

Harno E, Cottrell EC, White A (2013) Metabolic pitfalls of CNS cre-based technology. Cell Metab 18:21-28. CrossRef Medline

Hedrick T, Danskin B, Larsen RS, Ollerenshaw D, Groblewski P, Valley M, Olsen S, Waters J (2016) Characterization of channelrhodopsin and archaerhodopsin in cholinergic neurons of Cre-Lox transgenic mice. PLoS One 11:e0156596. CrossRef Medline

Kharkwal G, Brami-Cherrier K, Lizardi-Ortiz JE, Nelson AB, Ramos M, Del Barrio D, Sulzer D, Kreitzer AC, Borrelli E (2016) Parkinsonism driven by antipsychotics originates from dopaminergic control of striatal cholinergic interneurons. Neuron 91:67-78. CrossRef Medline

Kim TH, Richards K, Heng J, Petrou S, Reid CA (2013) Two lines of transgenic mice expressing cre-recombinase exhibit increased seizure susceptibility. Epilepsy Res 104:11-16. CrossRef Medline

Kolisnyk B, Guzman MS, Raulic S, Fan J, Magalhães AC, Feng G, Gros R, Prado VF, Prado MA (2013) ChAT-ChR2-EYFP mice have enhanced motor endurance but show deficits in attention and several additional cognitive domains. J Neurosci 33:10427-10438. CrossRef Medline

Liu S, Shao Z, Puche A, Wachowiak M, Rothermel M, Shipley MT (2015) Muscarinic receptors modulate dendrodendritic inhibitory synapses to sculpt glomerular output. J Neurosci 35:5680-5692. CrossRef Medline

Nair SG, Strand NS, Neumaier JF (2013) DREADDing the lateral habenula: a review of methodological approaches for studying lateral habenula function. Brain Res 1511:93-101. CrossRef Medline

Roseberry TK, Lee AM, Lalive AL, Wilbrecht L, Bonci A, Kreitzer AC (2016) Cell-type-specific control of brainstem locomotor circuits by basal ganglia. Cell 164:526-537. CrossRef Medline 
Rossi J, Balthasar N, Olson D, Scott M, Berglund E, Lee CE, Choi MJ, Lauzon D, Lowell BB, Elmquist JK (2011) Melanocortin-4 receptors expressed by cholinergic neurons regulate energy balance and glucose homeostasis. Cell Metab 13:195-204. CrossRef Medline

Schäfer MK, Eiden LE, Weihe E (1998) Cholinergic neurons and terminal fields revealed by immunohistochemistry for the vesicular acetylcholine transporter: I. central nervous system. Neuroscience 84:331-359. CrossRef Medline

Schmidt EE, Taylor DS, Prigge JR, Barnett S, Capecchi MR (2000) Illegitimate cre-dependent chromosome rearrangements in transgenic mouse spermatids. Proc Natl Acad Sci U S A 97:13702-13707. CrossRef Medline

Schmidt-Supprian M, Rajewsky K (2007) Vagaries of conditional gene targeting. Nat Immunol 8:665-668. CrossRef Medline

Smith RS, Hu R, DeSouza A, Eberly CL, Krahe K, Chan W, Araneda RC (2015) Differential muscarinic modulation in the olfactory bulb. J Neurosci 35:10773-10785. CrossRef Medline

Sugita S, Fleming LL, Wood C, Vaughan SK, Gomes MP, Camargo W, Naves LA, Prado VF, Prado MA, Guatimosim C, Valdez G (2016) VAChT overexpression increases acetylcholine at the synaptic cleft and accelerates aging of neuromuscular junctions. Skelet Muscle 6:31. CrossRef Medline

Tallini YN, Shui B, Greene KS, Deng KY, Doran R, Fisher PJ, Zipfel W, Kotlikoff MI (2006) BAC transgenic mice express enhanced green fluorescent protein in central and peripheral cholinergic neurons. Physiol Genomics 27:391-397. CrossRef Medline

Tarantino LM, Bucan M (2000) Dissection of behavior and psychiatric disorders using the mouse as a model. Hum Mol Genet 9:953-965. CrossRef Medline

Ting JT, Feng G (2014) Recombineering strategies for developing next generation BAC transgenic tools for optogenetics and beyond. Front Behav Neurosci 8:111. CrossRef Medline

Van Dort CJ, Zachs DP, Kenny JD, Zheng S, Goldblum RR, Gelwan NA, Ramos DM, Nolan MA, Wang K, Weng FJ, Lin Y, Wilson MA, Brown EN
(2015) Optogenetic activation of cholinergic neurons in the PPT or LDT induces REM sleep. Proc Natl Acad Sci U S A 112:584-589. CrossRef Medline

Võikar V, Kõks S, Vasar E, Rauvala H (2001) Strain and gender differences in the behavior of mouse lines commonly used in transgenic studies. Physiol Behav 72:271-281. CrossRef Medline

Witten IB, Steinberg EE, Lee SY, Davidson TJ, Zalocusky KA, Brodsky M, Yizhar O, Cho SL, Gong S, Ramakrishnan C, Stuber GD, Tye KM, Janak PH, Deisseroth K (2011) Recombinase-driver rat lines: tools, techniques, and optogenetic application to dopamine-mediated reinforcement. Neuron 72:721-733. CrossRef Medline

Xu M, Chung S, Zhang S, Zhong P, Ma C, Chang WC, Weissbourd B, Sakai N, Luo L, Nishino S, Dan Y (2015) Basal forebrain circuit for sleep-wake control. Nat Neurosci 18:1641-1647. CrossRef Medline

Yasuda M, Mayford MR (2006) CaMKII activation in the entorhinal cortex disrupts previously encoded spatial memory. Neuron 50:309-318. CrossRef Medline

Yi F, Catudio-Garrett E, Gábriel R, Wilhelm M, Erdelyi F, Szabo G, Deisseroth K, Lawrence J (2015) Hippocampal "cholinergic interneurons" visualized with the choline acetyltransferase promoter: anatomical distribution, intrinsic membrane properties, neurochemical characteristics, and capacity for cholinergic modulation. Front Synaptic Neurosci 7:4. CrossRef Medline

Zant JC, Kim T, Prokai L, Szarka S, McNally J, McKenna JT, Shukla C, Yang C, Kalinchuk AV, McCarley RW, Brown RE, Basheer R (2016) Cholinergic neurons in the basal forebrain promote wakefulness by actions on neighboring non-cholinergic neurons: an opto-dialysis study. J Neurosci 36:2057-2067. CrossRef Medline

Zhao S, Ting JT, Atallah HE, Qiu L, Tan J, Gloss B, Augustine GJ, Deisseroth K, Luo M, Graybiel AM, Feng G (2011) Cell type-specific channelrhodopsin-2 transgenic mice for optogenetic dissection of neural circuitry function. Nat Methods 8:745-752. CrossRef Medline 